\title{
AKTIVITAS INHIBISI ASETILKOLINESTERASE EMPAT JENIS SAYURAN SECARA IN VITRO
}

\author{
Maulita Cut Nuria ${ }^{* 1,3)}$, Elin Yulinah Sukandar ${ }^{2)}$, Asep Gana Suganda ${ }^{1)}$, Muhamad \\ Insanu $^{1)}$ \\ ${ }^{1)}$ Kelompok Keilmuan Biologi Farmasi, Sekolah Farmasi, Institut Teknologi Bandung, Jl. Ganesha \\ 10, Bandung \\ ${ }^{2)}$ Kelompok Keilmuan Farmakologi, Sekolah Farmasi, Institut Teknologi Bandung, Jl. Ganesha 10, \\ Bandung \\ ${ }^{3)}$ Bagian Biologi Farmasi, Fakultas Farmasi, Universitas Wahid Hasyim, Jl. Menoreh Tengah \\ $X / 22$, Semarang \\ Email: cut.nuria@yahoo.com; Nomor telepon:0811250380
}

\section{INTISARI}

Asetilkolin merupakan senyawa penghantar rangsang saraf (neurotransmitter), sedangkan asetilkolinesterase adalah enzim yang dapat menghidrolisis neurotransmiter asetilkolin menjadi kolin dan asam asetat. Reaksi ini diperlukan supaya saraf bisa kembali beristirahat setelah proses aktivasi, tetapi hal tersebut dapat menyebabkan kerusakan pada sel-sel di otak apabila terjadi berlebihan. Kasus yang paling umum terjadi adalah kepikunan yang ditandai dengan penurunan daya ingat. Prevalensi penyakit ini lebih rendah di negara Cina dan beberapa negara Asia lainnya dibandingkan dengan Amerika Serikat. Hal ini diduga karena jenis makanan yang biasa dikonsumsi oleh orang Asia adalah sayuran yang berasal dari bahan sayuran berpotensi menghambat aktivitas enzim asetilkolinesterase yang terkait dengan kandungan kimia tumbuhan tersebut. Tujuan penelitian ini adalah menentukan aktivitas inhibisi enzim asetilkolinesterase (AChE) dari 4 jenis sayuran yakni kecambah kedelai (bean sprout of Glycine max (L.) Merr.), kecambah kacang hijau (bean sprout of Vigna radiata), umbi wortel (Daucus carota L.), dan kecipir (Psophocarpus tetragonolobus (L.) DC.) secara in vitro dengan metode Ellman. Kadar fenolik dan flavonoid total dari keempat jenis ekstrak tersebut juga ditentukan. Ekstrak kecipir memiliki kadar fenolik dan flavonoid total paling kecil, tetapi aktivitas inhibisinya terhadap AChE paling besar. Hasil penelitian menunjukkan bahwa nilai $\mathrm{IC}_{50}$ ekstrak kecipir sebesar 893,86 $\mu \mathrm{g} / \mathrm{ml}$, ekstrak umbi wortel di atas $1500 \mu \mathrm{g} / \mathrm{ml}$ sedangkan ekstrak lainnya tidak memiliki aktivitas. Ekstrak kecipir potensial untuk dikembangkan lebih lanjut sebagai inhibitor AChE.

Kata kunci: inhibitor asetilkolinesterase, $\mathrm{IC}_{50}$, sayuran.

\section{ABSTRACT}

Acetylcholine is a conducting compound of nerve excitatory (neurotransmitter), while acetylcholinesterase is an enzyme that can hydrolyze the acetylcholine into choline and acetic acid. This reaction is needed so that the nerves can return to take a rest after the activation process, but it can cause damage to the cells in the brain. The most common case is dementia characterized by memory loss. The prevalence of this disease is lower in China and some other Asian countries compared to the United States. It supposed because food consumption commonly by Asians contain vegetables. Extracts derived from vegetables potentially inhibit the activity of acetylcholinesterase (AChE) enzyme which related to chemical contents of the plant. This research aims to investigate the inhibitory activity of acetylcholinesterase enzyme from 4 types of vegetables namely soybean sprouts (bean sprout of Glycine $\max (L$.$) Merr.), green bean sprouts (bean sprout of Vigna$ radiata), carrot (Daucus carota L.), and winged beans (Psophocarpus tetragonolobus (L.) DC.) by 
in vitro with the Ellman method. Total phenolic and flavonoids contents from fourth types of extracts were also determined. The winged beans extract had the smallest total phenolic and flavonoid contents, but the inhibitory activity against AChE was the biggest. The results showed that $I C_{50}$ extract of winged beans was $893.86 \mu \mathrm{g} / \mathrm{ml}, I C_{50}$ carrot extract higher than $1500 \mu \mathrm{g} / \mathrm{ml}$ while the other extracts had no activity. The winged beans extract potential to be further developed as an inhibitor AChE.

Keywords : inhibitor of acetylcholinesterase, $I C_{50}$, vegetables

*Corresponding author:

Maulita Cut Nuria

Bagian Biologi Farmasi, Fakultas Farmasi, Universitas Wahid Hasyim

Jl. Menoreh Tengah X/22, Semarang

Email: cut.nuria@yahoo.com

\section{PENDAHULUAN}

Asetilkolin merupakan senyawa penghantar rangsang saraf (neurotransmitter) yang disintesis di dalam ujung serabut saraf motorik melalui proses asetilasi kolin ekstrasel dan asetil koenzim A dengan bantuan enzim kolinasetil transferase. Setelah pelepasannya ke celah sinap, asetilkolin dihidrolisis oleh enzim asetilkolinesterase endogen menjadi kolin dan asetat (Perry dkk., 1999). Reaksi ini diperlukan supaya saraf bisa kembali beristirahat setelah proses aktivasi, tetapi hal tersebut dapat menyebabkan kerusakan pada sel-sel di otak. Kasus yang paling umum terjadi adalah kepikunan yang ditandai dengan penurunan daya ingat.

Umumnya penderita kepikunan adalah dari kelompok manusia lanjut usia (lansia). Prevalensi penyakit ini lebih rendah di Cina dan beberapa negara Asia lainnya dibandingkan dengan Amerika Serikat. Hal ini diduga kuat karena jenis makanan yang biasa dikonsumsi oleh orang Asia umumnya mengandung sayuran salah satunya adalah kecambah (Kausler dkk., 2007), namun hal ini masih perlu dibuktikan melalui penelitian ilmiah.

Selama berabad-abad, tumbuhan telah digunakan sebagai sumber makanan dan juga sebagai obat tradisional untuk meningkatkan daya ingat akibat usia lanjut (Mukherjee dan Houghton, 2009). Beberapa jenis sayuran menunjukkan aktivitas inhibisi asetilkolinesterase sehingga berpotensi meningkatkan memori. Sayuran tersebut diantaranya herba seledri, daun peterseli (Szwajgier dan Borowiec, 2012), daun kubis ungu (Boga dkk., 2011), daun kubis putih, daun ubi jalar (Septiningsih dan Suganda, 2013) dan daun kangkung (Dhanasekaran dkk., 2015).

Tujuan penelitian ini adalah untuk membuktikan adanya aktivitas inhibisi enzim asetilkolinesterase dari 4 jenis sayuran, yakni kecambah kedelai (bean sprout of Glycine max (L.) Merr.), kecambah kacang hijau (bean sprout of Vigna radiata), umbi wortel (Daucus carota L.), dan kecipir (Psophocarpus tetragonolobus (L.) DC.) secara in vitro dengan metode Ellman.

\section{METODE PENELITIAN \\ Bahan tanaman}

Bahan tanaman diperoleh dari daerah di Jawa Barat dan Jawa Tengah, Indonesia. Umbi wortel dan kecipir dipanen dari sumber budidaya di daerah Jawa Barat, yakni umbi wortel berasal dari Lembang sedangkan kecipir berasal dari Bogor. Kecambah kacang hijau dan kecambah kedelai diperoleh dari Semarang, Jawa Tengah. Bahan-bahan tersebut dilakukan determinasi di Herbarium Institut Teknologi Bandung. Berdasarkan penelusuran pustaka, kandungan kimia yang terdapat dalam keempat jenis sayuran tersebut tersaji pada Tabel I.

\section{Alat penelitian}

Alat yang digunakan meliputi: alat-alat gelas yang umum digunakan di laboratorium, almari pengering, neraca analitik (Mettler), bejana maserasi, rotary evaporator (Buchi Interface I-300 dan Heidolph), spektrofotometer UV-Vis, dan Elisa reader (Tecan Infinite 200 pro). 


\section{Jalannya Penelitian}

\section{Ekstraksi bahan tanaman}

Bahan tanaman dikeringkan pada temperatur $40-50^{\circ} \mathrm{C}$ dan diserbuk. Bahan kering tersebut diekstraksi secara maserasi dengan pelarut etanol 95\%. Proses tersebut dilakukan selama 3 hari dan tiap harinya dilakukan remaserasi menggunakan pelarut baru. Maserat yang dihasilkan kemudian diuapkan pelarutnya menggunakan rotary evaporator sehingga membentuk ekstrak kental. Ekstrak kental disimpan dalam desikator sebelum digunakan.

Tabel I. Daftar tanaman, bagian tanaman yang digunakan serta kandungan kimianya

\begin{tabular}{|c|c|c|c|}
\hline Nama botani & $\begin{array}{l}\text { Nama } \\
\text { Indonesia }\end{array}$ & $\begin{array}{l}\text { Bagian tanaman } \\
\text { yang digunakan }\end{array}$ & Kandungan kimia \\
\hline Daucus carota $\mathrm{L}$. & Wortel & Umbi & $\begin{array}{l}\text { Flavonoid (Miean dan Mohamed, } \\
\text { 2001) }\end{array}$ \\
\hline $\begin{array}{l}\text { Psophocarpus } \\
\text { tetragonolobus (L.) } \\
\text { DC. }\end{array}$ & Kecipir & Polong & $\begin{array}{l}\text { Asam kafeat dan asam } p \text {-kumarat } \\
\text { (Wongsa dkk. 2012). }\end{array}$ \\
\hline $\begin{array}{l}\text { Bean sprout Vigna } \\
\text { radiate }\end{array}$ & $\begin{array}{l}\text { Kecambah } \\
\text { kacang hijau }\end{array}$ & Kecambah & $\begin{array}{l}\text { Flavon, isoflavon, flavonoid, } \\
\text { (Prokudina dkk. 2012; Wang dkk. } \\
\text { 2008), asam fenolat dan asam } \\
\text { organik (Tang dkk. 2014) }\end{array}$ \\
\hline $\begin{array}{l}\text { Bean sprout } \\
\text { Glycine max (L.) } \\
\text { Merr. }\end{array}$ & $\begin{array}{l}\text { Kecambah } \\
\text { kedelai }\end{array}$ & Kecambah & $\begin{array}{l}\text { Isoflavon (Sakakibara dkk. 2003); } \\
\text { sterol, phytic acid (Lee dkk. } \\
\text { 2013); } \alpha \text {-tokoferol (Ching dan } \\
\text { Mohamed, 2001) }\end{array}$ \\
\hline
\end{tabular}

\section{Pembuatan larutan induk ekstrak}

Ekstrak ditimbang 0,5 gram kemudian ditambah $5 \mathrm{~mL}$ etanol p.a. Larutan ekstrak diaduk menggunakan magnetic stirer pada kecepatan $500 \mathrm{rpm}$, disaring dan filtrat yang diperoleh ditambah etanol ad $25 \mathrm{ml}$. Konsentrasi larutan induk ekstrak adalah $20.000 \mu \mathrm{g} / \mathrm{mL}$.

\section{Pengukuran panjang gelombang maksimum}

Pengukuran panjang gelombang maksimum untuk flavonoid dilakukan dengan membuat larutan standar kuersetin pada konsentrasi $6 \mu \mathrm{g} / \mathrm{mL}$. Larutan kompleks kuersetin- $\mathrm{AlCl}_{3}$ diukur menggunakan spektrofotometer visibel pada panjang gelombang $390-550 \mathrm{~nm}$, dengan nilai absorbansi larutan antara 0,2-0,8. Panjang gelombang maksimum yang diperoleh untuk senyawa kompleks kuersetin- $\mathrm{AlCl}_{3}$ adalah $422,9 \mathrm{~nm}$.

Pengukuran panjang gelombang maksimum untuk fenolik dilakukan dengan membuat larutan standar asam galat pada konsentrasi $50 \mu \mathrm{g} / \mathrm{mL}$ kemudian diambil $200 \mu \mathrm{L}$ ditambahkan $0,4 \mathrm{~mL}$ reagen Folin Ciocalteu, dikocok dan dibiarkan 8 menit. Larutan tersebut ditambahkan $4 \mathrm{~mL}$ larutan $\mathrm{Na}_{2} \mathrm{CO}_{3} 7 \%$, dikocok hingga homogen, diukur menggunakan spektrofotometer visibel pada panjang gelombang 550-800 $\mathrm{nm}$. Panjang gelombang maksimum yang diperoleh untuk senyawa kompleks molibdenum-tungsten adalah 763,0 nm.

\section{Penentuan operating time}

Penentuan operating time atau waktu operasional untuk flavonoid dilakukan terhadap larutan kompleks kuersetin- $\mathrm{AlCl}_{3}$ konsentrasi $6 \mu \mathrm{gg} / \mathrm{mL}$. Larutan tersebut diukur menggunakan spektrofotometer visibel pada panjang gelombang $422,9 \mathrm{~nm}$ dengan waktu pengukuran pada menit ke $0,5,10,15,20,25,30,35,40,45,50,55$, dan 60 .

Penentuan operating time untuk fenolik dilakukan terhadap larutan asam galat konsentrasi $50 \mu \mathrm{g} / \mathrm{mL}$ kemudian diambil $200 \mu \mathrm{L}$, ditambahkan $0,4 \mathrm{~mL}$ reagen Folin Ciocalteu, dikocok dan dibiarkan 8 menit, ditambahkan $4 \mathrm{~mL}$ larutan $\mathrm{Na}_{2} \mathrm{CO}_{3} 7 \%$, dikocok hingga homogen. Senyawa kompleks molibdenum-tungsten tersebut diukur menggunakan spektrofotometer visibel pada panjang gelombang 763,0 nm dengan waktu pengukuran pada menit ke 0, 5, 10, 15, 30, 45, 60, 75, 90, 105, 120, 135, 150, 165 dan 180. Penentuan operating time ditentukan dengan melihat nilai absorbansi yang stabil pada hasil pengukuran. 


\section{Pembuatan kurva baku}

Pembuatan kurva baku kuersetin dilakukan dengan membuat larutan kuersetin pada seri konsentrasi 2, 4, 6, 8, 10 dan $12 \mu \mathrm{g} / \mathrm{mL}$. Pembuatan kurva baku asam galat dilakukan dengan membuat larutan asam galat pada seri konsentrasi 50, 100, 150, 200, 250 dan $300 \mu \mathrm{g} / \mathrm{mL}$. Senyawa kompleks berwarna yang dihasilkan dari masing-masing larutan tersebut kemudian diukur dengan spektrofotometer visibel pada panjang gelombang maksimum.

\section{Pengukuran kadar flavonoid total}

Analisis kuantitatif kadar flavonoid total dari keempat jenis ekstrak dilakukan dengan metode kolorimetri menggunakan pereaksi $\mathrm{AlCl}_{3}$ (Chang dkk., 2002). Larutan uji masing-masing ekstrak diambil sebanyak $1000 \mu \mathrm{L}$, kemudian ditambahkan 1,5 mL etanol p.a, $200 \mu \mathrm{L} \mathrm{AlCl}_{3} 10 \%$, dan $200 \mu \mathrm{L}$ Kalium asetat $1 \mathrm{M}$. Operating time selama 30 menit dan absorbansi diukur pada panjang gelombang 422,9 $\mathrm{nm}$. Kadar flavonoid total dinyatakan sebagai jumlah mg kuersetin (QE) yang ekuivalen pada tiap gram ekstrak.

\section{Pengukuran kadar fenolik total}

Analisis kuantitatif kadar fenolik total pada keempat jenis ekstrak dilakukan dengan metode Folin Ciocalteu (Ahmad dkk., 2015). Larutan uji masing-masing ekstrak diambil sebanyak $200 \mu \mathrm{L}$ ditambahkan 0,4 mL reagen Folin-Ciocalteu, dikocok dan dibiarkan 8 menit, ditambahkan $4 \mathrm{~mL}$ larutan $\mathrm{Na}_{2} \mathrm{CO}_{3} 7 \%$, dikocok hingga homogen. Operating time selama 2 jam dan absorbansi diukur pada panjang gelombang $763,0 \mathrm{~nm}$. Kadar fenolik total dinyatakan sebagai jumlah mg asam galat (GAE) yang ekuivalen pada tiap gram ekstrak.

\section{Penentuan aktivitas inhibisi enzim asetilkolinesterase secara in vitro}

Aktivitas enzim diukur menggunakan microplate 96-well dan uji tersebut telah dijabarkan oleh Mathew dan Subramanian (2014) dengan sedikit modifikasi berdasarkan metode Ellman. Enzim asetilkolinesterase (AChE) akan menghidrolisis substrat asetiltiokolin (ATCI) yang menghasilkan produk tiokolin. Tiokolin yang terbentuk direaksikan dengan 5-5'-dithiobis-2nitrobenzoic acid (DTNB) dan menghasilkan 5-thio-2-nitrobenzoic acid (TNB) yang berwarna kuning dan intensitasnya diukur menggunakan spektrofotometer UV-Vis pada panjang gelombang $412 \mathrm{~nm}$.

Larutan Tris- $\mathrm{HCl} 50 \mathrm{mM} \mathrm{pH} 8,0$ digunakan sebagai bufer selama proses eksperimen berlangsung, kecuali dinyatakan lain dalam penelitian ini. Enzim asetilkolinesterase yang digunakan untuk uji diperoleh dari Electric eel (product number C3389, $500 \mathrm{U} / \mathrm{mg}$ solid, SigmaAldrich). Enzim yang telah dilarutkan dalam bufer harus disimpan pada suhu $-20^{\circ} \mathrm{C}$ untuk kepentingan penelitian ini. DTNB dilarutkan dalam bufer yang mengandung $0,1 \mathrm{M} \mathrm{NaCl}$ dan $0,02 \mathrm{M} \mathrm{MgCl}_{2}$. ATCI dilarutkan dalam aqua deion.

Sebanyak $100 \mu \mathrm{l}$ DTNB $3 \mathrm{mM}, 20 \mu \mathrm{l}$ AChE $0,26 \mathrm{U} / \mathrm{ml}$, dan $60 \mu \mathrm{l}$ dari setiap ekstrak pada beberapa konsentrasi $(500,750,1000,1250$ and $1500 \mu \mathrm{g} / \mathrm{ml})$ dilarutkan dalam bufer yang mengandung tidak lebih dari $10 \%$ metanol, ditambahkan pada masing-masing sumuran. Setelah proses pencampuran, microplate 96 -well tersebut diinkubasi pada suhu $25^{\circ} \mathrm{C}$ selama 15 menit dan serapannya diukur pada $412 \mathrm{~nm}$. Hasil pembacaan tersebut digunakan sebagai blanko. Reaksi enzimatik diinisiasi dengan penambahan $20 \mu \mathrm{L}$ ATCI $15 \mathrm{mM}$ (Sigma-Aldrich) sehingga senyawa TNB yang dihasilkan dapat diukur dengan membaca serapan setiap 5 menit selama 30 menit. Pyridostigmin digunakan sebagai baku pembanding dalam penelitian ini. Masing-masing bahan uji dilakukan replikasi sebanyak tiga kali. Nilai persen inhibisi dihitung sebagai berikut:

$$
\text { Persen Inhibisi }(\%)=[(\mathrm{A}-\mathrm{E}) / \mathrm{A}] \times 100
$$

keterangan: A adalah aktivitas enzim tanpa penambahan ekstrak dan $\mathrm{E}$ adalah aktivitas enzim dengan penambahan ekstrak.

\section{ANALISIS DATA}

Data absorbansi dari seri konsentrasi kuersetin dan asam galat kemudian dibuat persamaan kurva baku. Persamaan kurva baku adalah $\mathrm{y}=\mathrm{bx}+\mathrm{a}$ dengan $\mathrm{y}=$ absorbansi, $\mathrm{x}=\mathrm{kadar}$ kuersetin atau asam galat dalam $\mu \mathrm{g} / \mathrm{mL}$. Nilai absorbansi dari keempat jenis ekstrak tersebut dimasukkan ke 
dalam persamaan kurva baku kuersetin dan asam galat, sehingga didapatkan kadar flavonoid atau fenolik $(\mu \mathrm{g} / \mathrm{mL})$.

Kadar flavonoid dan fenolik total dihitung sebagai berikut:

$$
F=\frac{c \times V \times f}{m}
$$

Keterangan: $\quad \mathrm{F}=$ Kadar Flavonoid, Fenolik (mg/gram ekstrak)

$\mathrm{c}=$ Kesetaraan Kuersetin atau asam galat $(\mu \mathrm{g} / \mathrm{mL})$

$\mathrm{V}=$ Volume Total Ekstrak (mL)

$\mathrm{f}=$ Faktor Pengenceran

$\mathrm{m}=$ Berat Sampel (gram)

Aktivitas inhibisi enzim asetilkolinesterase $(\mathrm{AChE})$ dinyatakan dengan $\mathrm{IC}_{50}$. Nilai $\mathrm{IC}_{50}$ dapat dihitung dari nilai persen inhibisi beberapa seri konsentrasi ekstrak pada masing-masing ekstrak uji. Nilai $\mathrm{IC}_{50}$ dihitung menggunakan regresi linear dengan bantuan piranti lunak Microsoft Excel.

\section{HASIL DAN PEMBAHASAN}

Tahap awal penelitian adalah penyiapan simplisia dan pembuatan ekstrak etanol dari masingmasing jenis sayuran yang digunakan. Proses pengeringan dilakukan pada suhu $40-50^{\circ} \mathrm{C}$ dan proses ekstraksi juga menggunakan metode dingin (maserasi) untuk meminimalkan kerusakan bahan aktif yang tidak tahan panas atau mudah menguap. Tabel II menunjukkan rendemen simplisia dan rendemen ekstrak dari masing-masing jenis sayuran.

\section{Tabel II. Jenis sayuran, nilai rendemen simplisia dan ekstraknya}

\begin{tabular}{lcc}
\hline Jenis sayuran & Rendemen simplisia (\%) & Rendemen ekstrak (\%) \\
\hline Wortel & 8,14 & 30,18 \\
Kecipir & 5,56 & 11,76 \\
Kecambah kacang hijau & 9,88 & 13,54 \\
Kecambah kedelai & 20,85 & 4,12 \\
\hline
\end{tabular}

Nilai rendemen simplisia menyatakan perolehan kembali bahan tanaman setelah proses pengeringan. Bila rendemen simplisia kecil maka bahan tanaman tersebut banyak mengandung air, sehingga dibutuhkan lebih banyak bahan segar untuk mendapatkan ekstrak dalam jumlah yang cukup untuk proses pengujian. Tabel II menunjukkan bahwa kecipir memiliki rendemen simplisia paling kecil sedangkan kecambah kedelai memiliki rendemen simplisia paling besar.

Rendemen ekstrak menyatakan perolehan kembali bahan simplisia setelah proses ekstraksi. Nilai rendemen ekstrak yang besar menunjukkan bahwa senyawa-senyawa kimia yang terkandung dalam simplisia lebih banyak tersari dalam pelarut yang digunakan. Rendemen ekstrak yang paling besar adalah wortel sedangkan yang paling kecil adalah kecambah kedelai. Hasil penelitian menunjukkan bahwa kecambah kedelai memiliki rendemen simplisia terbesar namun rendemen ekstraknya terkecil. Hal ini berarti bahwa meskipun kecambah kedelai tidak terlalu banyak mengandung air dibandingkan bahan lainnya, namun ternyata senyawa-senyawa kimia yang terkandung didalamnya tidak banyak yang tersari dalam pelarut etanol 95\%. Menurut Astawan dan Hazmi (2016), kecambah kedelai mengandung lemak, protein, mineral, dan karbohidrat dalam jumlah yang cukup besar. Hal inilah yang kemungkinan menyebabkan kandungan senyawa kimia dalam kecambah kedelai relatif sedikit, sehingga tidak banyak yang tersari dalam etanol $95 \%$.

Penelitian ini juga menentukan karakteristik kimia dari keempat jenis ekstrak yaitu kadar fenolik total dan kadar flavonoid total (Tabel III). Berdasarkan hasil penentuan kurva baku kuersetin diperoleh persamaan regresi linear $y=0,04942 x+0,14529(x=k a d a r$ flavonoid total dalam $\mu \mathrm{g} / \mathrm{mL}, \mathrm{y}=\mathrm{absorbansi)}$ dengan nilai koefesien korelasi $\mathrm{r}=0,99828$, sedangkan persamaan kurva baku asam galat diperoleh $y=0,00207 x+0,13513(x=k$ adar fenolik total dalam $\mu \mathrm{g} / \mathrm{mL}$, $\mathrm{y}=\mathrm{absorbansi)}$ dengan nilai koefesien korelasi $\mathrm{r}=0,99879$. 
Tabel III memperlihatkan bahwa ekstrak kecipir memiliki kadar fenolik total dan kadar flavonoid total paling kecil, sedangkan ekstrak kecambah kacang hijau memiliki kadar fenolik total terbesar dan ekstrak wortel memiliki kadar flavonoid total terbesar. Perbedaan karakteristik ekstrak secara kimia sangat dipengaruhi oleh kandungan kimia dari tanaman. Senyawa golongan fenolik lebih banyak ditemukan pada ekstrak kecambah kacang hijau. Asam fenolat merupakan komponen yang ada dalam kecambah kacang hijau (Tang dkk., 2014). Chatatikun dan Chiabchalard (2013) melaporkan bahwa ekstrak etanol umbi wortel memiliki kadar flavonoid total sebesar 20,4 $\pm 2,8 \mathrm{mg}$ kuersetin $(\mathrm{QE})$ yang ekuivalen pada tiap gram bahan kering. Hasil tersebut hampir sama seperti hasil yang didapatkan pada penelitian ini.

Tabel III. Jenis ekstrak serta kadar fenolik total dan flavonoid total

\begin{tabular}{lcc}
\hline Jenis ekstrak & $\begin{array}{c}\text { Kadar fenolik total tiap gram } \\
\text { ekstrak (mg/gram ekstrak) }\end{array}$ & $\begin{array}{c}\text { Kadar flavonoid total } \\
\text { tiap gram ekstrak } \\
\text { (mg/gram ekstrak) }\end{array}$ \\
\hline Wortel & $12,67 \pm 0,67$ & $22,77 \pm 0,55$ \\
Kecipir & $5,25 \pm 0,081$ & $0,10 \pm 0,004$ \\
Kecambah kacang hijau & $597,67 \pm 4,83$ & $13,14 \pm 0,05$ \\
Kecambah kedelai & $7,69 \pm 0,22$ & $0,21 \pm 0,003$ \\
\hline
\end{tabular}

Ekstrak etanol dari 4 jenis sayuran telah diuji aktivitas inhibisi AChE menggunakan metode Ellman. Hasilnya disajikan pada Tabel IV yang menunjukkan nilai persen inhibisi pada konsentrasi ekstrak $1000 \mu \mathrm{g} / \mathrm{ml}$ dan $1500 \mu \mathrm{g} / \mathrm{ml}$. Ekstrak kecambah kacang hijau dan kecambah kedelai ternyata tidak memiliki aktivitas sebagai inhibitor AChE. Pada saat percobaan, nilai kecepatan reaksinya cenderung meningkat seiring waktu pengamatan bila dibandingkan dengan perlakuan enzim tanpa ekstrak. Oleh karena itu kedua ekstrak tersebut tidak bersifat menginhibisi, melainkan bersifat menginduksi enzim AChE. Ekstrak umbi wortel memiliki nilai persen inhibisi yang relatif kecil pada konsentrasi yang cukup besar, yaitu sekitar 11-20\% pada konsentrasi 1000-1500 $\mu \mathrm{g} / \mathrm{ml}$. Adapun ekstrak kecipir menghasilkan nilai persen inhibisi sebesar 52-75\% pada konsentrasi $1000-1500 \mu \mathrm{g} / \mathrm{ml}$. Berdasarkan penelusuran pustaka yang telah dilakukan, biasanya suatu bahan alam dikatakan berpotensi sebagai inhibitor $\mathrm{AChE}$ jika memiliki nilai $\mathrm{IC}_{50}$ lebih kecil daripada $1000 \mu \mathrm{g} / \mathrm{ml}$. Oleh karena itu penentuan nilai $\mathrm{IC}_{50}$ hanya dilakukan pada ekstrak kecipir saja, sedangkan ekstrak umbi wortel nilai $\mathrm{IC}_{50}$ dinyatakan lebih besar daripada $1500 \mu \mathrm{g} / \mathrm{ml}$.

Tabel IV. Nilai persen inhibisi dari masing-masing ekstrak

\begin{tabular}{lcc}
\hline Jenis ekstrak & $\begin{array}{c}\text { Inhibisi AChE pada } \\
\text { konsentrasi ekstrak } \\
1000 \mu \mathrm{g} / \mathrm{ml}(\%)\end{array}$ & $\begin{array}{c}\text { Inhibisi AChE pada } \\
\text { konsentrasi ekstrak } \\
1500 \mu \mathrm{g} / \mathrm{ml}(\%)\end{array}$ \\
\hline Wortel & 11,93 & 21,68 \\
Kecipir & 52,32 & 75,70 \\
Kecambah kacang hijau & - & - \\
Kecambah kedelai & - & - \\
\hline
\end{tabular}

Pyridostigmin digunakan sebagai baku pembanding inhibitor AChE pada penelitian ini. Penggunaan baku pembanding bertujuan untuk validasi metode yang digunakan pada penelitian. Nilai $\mathrm{IC}_{50}$ pyridostigmin adalah $0,373 \pm 0,005 \mu \mathrm{g} / \mathrm{ml}$ sedangkan $\mathrm{IC}_{50}$ ekstrak kecipir sebesar $921,90 \pm 48,50 \mu \mathrm{g} / \mathrm{ml}$. Kecipir mengandung senyawa fenolik diantaranya asam kafeat dan asam p-kumarat, serta mempunyai aktivitas antioksidan (Wongsa dkk., 2012). Salah satu terapi kepikunan adalah menggunakan senyawa antioksidan yang diketahui memiliki aktivitas sebagai neuroprotektif. Sebagian besar obat yang telah digunakan untuk kepikunan merupakan inhibitor AChE dengan cara menurunkan degradasi asetilkolin. Obat-obat ini memberikan banyak manfaat untuk perbaikan kualitas hidup pasien, sehingga beberapa peneliti menggabungkan molekul obat ini dengan senyawa antioksidan dengan harapan dapat meningkatkan keberhasilan terapi (Rosini dkk., 2014). Jika aktivitas inhibisi AChE ekstrak dikaitkan dengan kadar fenolik maupun flavonoid 
total, maka hal tersebut juga tidak signifikan korelasinya. Tabel III memperlihatkan bahwa ekstrak kecipir memiliki kadar fenolik dan flavonoid total paling kecil, namun ternyata aktivitas inhibisinya paling besar di antara keempat ekstrak uji. Hal ini berarti bahwa ada senyawa lain yang lebih berperan sebagai inhibitor $\mathrm{AChE}$ di dalam ekstrak kecipir tersebut.

Bila dibandingkan nilai $\mathrm{IC}_{50}$ ekstrak kecipir dengan pyridostigmin, maka aktivitas ekstrak masih sangat kecil. Hal ini dikarenakan ekstrak masih mengandung banyak senyawa-senyawa kimia sehingga aktivitasnya merupakan resultan dari interaksi semua senyawa-senyawa kimia tersebut. Interaksinya bisa bersifat saling memperkuat atau saling meniadakan, sehingga masih diperlukan tahapan lainnya dalam rangka memperbesar aktivitas inhibisi AChE dari ekstrak. Salah satu upaya yang dapat dilakukan adalah menyederhanakan kandungan kimia ekstrak dengan cara fraksinasi. Proses fraksinasi dapat memilah-milah kandungan kimia berdasarkan polaritasnya, misalnya dengan membuat fraksi non polar, semi polar dan polar. Harapannya adalah aktivitas inhibisinya dapat meningkat seiring dengan kandungan kimia yang lebih spesifik.

\section{KESIMPULAN DAN SARAN}

Hasil penelitian menunjukkan bahwa nilai $\mathrm{IC}_{50}$ asetilkolinesterase ekstrak kecipir sebesar $893,86 \mu \mathrm{g} / \mathrm{ml}$, ekstrak umbi wortel diatas $1500 \mu \mathrm{g} / \mathrm{ml}$ sedangkan ekstrak lainnya tidak memiliki aktivitas. Dalam rangka meningkatkan aktivitas inhibisi asetilkolinesterase ekstrak kecipir dapat dilakukan proses fraksinasi agar kandungan kimia ekstrak lebih sederhana sehingga aktivitasnya dapat meningkat.

\section{UCAPAN TERIMA KASIH}

Peneliti mengucapkan terima kasih kepada Direktorat Riset dan Pengabdian kepada Masyarakat, Direktorat Jenderal Penguatan Riset dan Pengembangan, Kementerian Riset, Teknologi dan Pendidikan Tinggi yang telah membiayai sebagian dana penelitian ini melalui skema "Penelitian Disertasi Doktor" 2017 atas nama Maulita Cut Nuria.

\section{DAFTAR PUSTAKA}

Ahmad, A.R., Juwita, Ratulangi, S.A.D. dan Malik, A., 2015, Penetapan Kadar Fenolik dan Flavonoid Total Ekstrak Metanol Buah dan Daun Patikala (Etlingera elatior (Jack) R.M.SM), Pharm Sci Res, 2, 1-10.

Astawan, M. dan Hazmi, K., 2016, Karakteristik fisikokimia tepung kecambah kedelai, Pangan, 25(2): 105-112.

Boga, M., Hacibekiroglu, I., Kolak, U., 2011, Antioxidant and anticholinesterase activities of eleven edible plants, Pharmaceutical Biology, 49(3): 290-295.

Chang, C., Yang, M., Wen, H., Chern, J., 2002, Estimation of total flavonoid content in propolis by two complementary colorimetric methods, J Food Drug Anal., 10, 178-182.

Chatatikun, M. dan Chiabchalard, A., 2013, Phytochemical screening and free radical scavenging activities of orange baby carrot and carrot (Daucus carota Linn.) root crude extracts, Journal of Chemical and Pharmaceutical Research, 5(4):97-102.

Dhanasekaran, S., Perumal, P., and Palayan, M., 2015, In-vitro screening for acetylcholinesterase enzyme inhibition potential and antioxidant activity of extracts of Ipomoea aquatica Forsk: therapeutic lead for alzheimer's disease, Journal of Applied Pharmaceutical Science, 5(02): 012-016.

Kausler, D.H., Kausler, B.C., and Krupsaw, J.A., 2007, The essential guide to aging in the twenty first century: Mind, body and behavior, Columbia and London: University of Missouri Press, P31-37.

Mathew, M. dan Subramanian, S., 2014, In vitro screening for anti-cholinesterase and antioxidant activity of methanolic extracts of Ayurvedic medicinal plants used for cognitive disorders, PLOS one, 9(1): 1-7.

Mukherjee, P.K. dan Houghton, P.J., 2009, The worldwide phenomenon of increased use of herbal products: opportunities and threats, Di dalam Mukherjee, P.K. dan Houghton, P.J. (eds.), Evaluation of herbal medicinal products - perspectives of quality, safety and efficacy, London: Pharmaceutical Press, P3-12. 
Perry, E., Walker, M., Grace, J., and Perry, R., 1999, Acetylcholine in mind: a neurotransmitter correlate of consciousness?, TINS, 22(6): 273-280

Rosini, M., Simoni, E., Milelli, A., Minarini, A., and Melchiorre, C., 2014, Oxidative stress in Alzheimer's disease: Are we connecting the dots?, J Med Chem, 57: 2821-2831.

Septiningsih, E. dan Suganda, A.G., 2013, Penghambatan aktivitas enzim asetilkolinesterase ekstrak metanol empat belas jenis tumbuhan, Jurnal Bahan Alam Indonesia, 8 (4): 248-252.

Szwajgier, D. dan Borowiec, K., 2012, Screening for cholinesterase inhibitors in selected fruits and vegetables, EJPAU, 15(2): \#06.

Tang, D., Dong, Y., Ren, H., Li, L., and He, C., 2014, A review of phytochemistry, metabolite changes, and medicinal uses of the common food mung bean and its sprouts (Vigna radiata), Chemistry Central Journal, 8(4): 1-9.

Wongsa, P., Chaiwarit, J., and Zamaludien, A., 2012, In vitro screening of phenolic compounds, potential inhibition against $\alpha$-amylase and $\alpha$-glucosidase of culinary herbs in Thailand, Food Chemistry, 131: $964-971$. 